\title{
Heavy Metals Concentrations in Leafy Vegetables in Palestine, Case Study: Jenin and Bethlehem Districts
}

\author{
Mahmoud AlKhatib', Ahmad Qutob' ${ }^{2}$, Elizabeth Kattan³ ${ }^{3}$ Husam Malassa ${ }^{3}$, Mutaz Qutob1,3* \\ ${ }^{1}$ Department of Chemistry and Chemical Technology, Al-Quds University, Jerusalem, Palestine \\ ${ }^{2}$ Department of Electrical Engineering, Faculty of Engineering, Al-Quds University, Jerusalem, Palestine \\ ${ }^{3}$ Department of Environment and Earth Studies, Al-Quds University, Jerusalem, Palestine \\ Email: ^kutob@staff.alquds.edu
}

How to cite this paper: AlKhatib, M., Qutob, A., Kattan, E., Malassa, H. and Qutob, M. (2022) Heavy Metals Concentrations in Leafy Vegetables in Palestine, Case Study: Jenin and Bethlehem Districts. Journal of Environmental Protection, 13, 97-111. https://doi.org/10.4236/jep.2022.131006

Received: November 17, 2021

Accepted: January, 14, 2022

Published: January, 17, 2022

Copyright $\odot 2022$ by author(s) and Scientific Research Publishing Inc. This work is licensed under the Creative Commons Attribution International License (CC BY 4.0).

http://creativecommons.org/licenses/by/4.0/

\begin{abstract}
This study investigates the concentrations of metals in leafy vegetables in Bethlehem and Jenin districts in Palestine. The concentrations of $\mathrm{Fe}, \mathrm{Pb}, \mathrm{Cr}$, $\mathrm{Co}, \mathrm{Cu}, \mathrm{Mn}, \mathrm{Cd}$, and $\mathrm{Zn}$ were measured. Vegetables including spinach, arugula, and parsley were collected from different farms from both regions, and analyzed by using ICP-MS. In Bethlehem region, Iron concentrations were ranged from 25 to $1046 \mathrm{mg} / \mathrm{kg}$. Iron concentrations were higher than the WHO/FAO limits of $425 \mathrm{mg} / \mathrm{kg}$ in $33 \%$ of the samples. Lead concentrations were ranged from 0.04 to $1.77 \mathrm{mg} / \mathrm{kg}$. Lead concentrations were higher than the WHO/FAO limits of $0.3 \mathrm{mg} / \mathrm{kg}$ in $40 \%$ of the samples. Chromium concentrations were ranged from 0.02 to $2.51 \mathrm{mg} / \mathrm{kg}$. Chromium concentrations were higher than the WHO/FAO limits of $1.3 \mathrm{mg} / \mathrm{kg}$ in $13 \%$ of the samples. Zinc concentrations were ranged from 4 to $107 \mathrm{mg} / \mathrm{kg}$. Zinc concentrations were higher than the WHO/FAO limits of $99.4 \mathrm{mg} / \mathrm{kg}$ in $6.6 \%$ of the samples. Cadmium concentrations were ranged from 0.01 to $1.4 \mathrm{mg} / \mathrm{kg}$. Cadmium concentrations were higher than the WHO/FAO limits of $0.2 \mathrm{mg} / \mathrm{kg}$ in $13 \%$ of the samples. The concentration of Manganese, Cobalt and Cupper were all below the WHO/FAO limits of 500, 50 and $73 \mathrm{mg} / \mathrm{kg}$ respectively. In Jenin region, Iron concentrations were ranged from 42 to $543 \mathrm{mg} / \mathrm{kg}$. Iron concentrations were higher than the WHO/FAO limits of $425 \mathrm{mg} / \mathrm{kg}$ in $20 \%$ of the samples. Lead concentrations were ranged from 0.05 to $0.67 \mathrm{mg} / \mathrm{kg}$. Lead concentrations were higher than the WHO/FAO limits of $0.3 \mathrm{mg} / \mathrm{kg}$ in $20 \%$ of the samples. Copper concentrations were ranged from 0.62 to $278 \mathrm{mg} / \mathrm{kg}$. Copper concentrations were higher than the WHO/FAO limits of $73 \mathrm{mg} / \mathrm{kg}$ in $6.66 \%$ of the samples. Cadmium concentrations were ranged from 0.02 to $1.62 \mathrm{mg} / \mathrm{kg}$. Cadmium concentrations were higher than the WHO/FAO limits
\end{abstract}


of $0.2 \mathrm{mg} / \mathrm{kg}$ in $6.66 \%$ of the samples. The concentration of Chromium, Manganese, Cobalt and Cupper were all below the WHO/FAO limits. It was concluded that the contamination found in some leafy vegetable samples was not related to either irrigation water or soil. It was attributed to the misuse of pesticides.

\section{Keywords}

Heavy Metals, Vegetables, Pesticides

\section{Introduction}

During the last decades, crops safety has become a major concern all over the world [1]. Metal contaminated crops are a primary pathway of heavy metal exposure to humans [2]. Metals could be toxic even at low concentrations. Heavy metals transferred to human body may cause diseases [3] and long-term risks to ecosystems and human health [4]. Heavy metals such as $\mathrm{Pb}$ are proven carcinogens [5]. High concentrations of $\mathrm{Pb}$ and $\mathrm{Cu}$ in crops are well known to cause upper gastrointestinal cancer [6]. In order to protect human health, it is necessary to control the levels of toxic metals in food stuffs [6]. The concentration of heavy metal in plants is influenced by many factors such as the nature of the soil, pollution, and the time of harvesting [7] [8]. Soil $\mathrm{pH}$ is also a major factor that influences the uptake of Metals by plants. The solubility and mobility of the metals increase as the acidity of the soil is increased ( $\mathrm{pH}$ decreases) [9] [10]. Anthropogenic activities could also lead to Metal contamination in crops. These activities include mining and metal processing, use of pesticides, sewage sludge, burning wastes and fuels, vehicle emissions and many other industrial processes [10] [11]. The use of fertilizers, in general, could contribute to metal pollution in vegetables [12] [13]. It is reported in the literature that the use of high amounts of phosphate fertilizer may increase arsenic (As), cadmium $(\mathrm{Cd})$, and lead $(\mathrm{Pb})$ concentrations in agricultural soils [14]. Therefore, monitoring and assessment of heavy metals concentrations in vegetables have been carried out in many countries all over the world [15].

Agriculture in Palestine faces true challenging conditions due to the political situation in the region [16]. These challenges include Political closures, dry seasons, water scarcity, fertilizer and pesticides restrictions for many reasons [16]. Concerning the use of fertilizers and pesticides in the west bank region of Palestine, Palestinian farmers are restricted from using fertilizers or pesticides by the Israeli authorities. Thus, farmers use cheap, chlorine-based fertilizers which are known to increase soil salinity and accelerate soil degradation, not to mention its negative impacts and accumulation in vegetables that end up affecting human health [16]. In 2012, the Palestinian Authority has set regulations on the management of pesticides [17]. These regulations involved registering the pesticide type, the quantity and the traders. The regulations forbid the use of banned pes- 
ticides as classified by WHO. Unfortunately, illegal trade of pesticides in the West Bank is still a challenge to control due to the political situation in the region [17], thus there is a very noticeable trade in illegal pesticides in the West Bank. It is speculated that as much as $50 \%$ of pesticides used in the country are illegal [17] [18]. All of these true challenges may increase metals concentration in the crops that are grown in Palestine.

This study investigates the concentrations of metals in leafy vegetables in two different regions. These two regions are Bethlehem and Jenin districts in the west bank region of Palestine. The two regions differ in their climate zones, rain fall, human activities and industrial activities. The concentrations of $\mathrm{Fe}, \mathrm{Pb}, \mathrm{Cr}$, $\mathrm{Co}, \mathrm{Cu}, \mathrm{Mn}, \mathrm{Cd}$, and $\mathrm{Zn}$ were measured. Vegetables including spinach, arugula, and parsley were collected from different farms in both regions. This study tackles the possibility of contamination with metals due to human activities and misuse of pesticides or chemical fertilizers. There are limited studies concerning the pollution of metals in the vegetables grown in the west bank region of Palestine (see [7] [19]). Therefore, this study is an important contribution to the assessment of vegetable contamination with heavy metals in the region.

\section{Experimental}

\subsection{Study Areas}

This study was conducted on target areas of Bethlehem and Jenin districts (Figure 1). Bethlehem represents the southern area, while Jenin represents the northern area in the west bank.

\subsubsection{Site 1: Bethlehem District}

Bethlehem is one of the governorates in Palestine. It is situated at an elevation of about 775 meters that is about 2543 feet above sea level. It lies to the south of Jerusalem [21]. It has a population of approximately 221,802 inhabitants [22]. Bethlehem Governorate has a total area of about $660 \mathrm{~km}^{2}$. The governorate consists of many municipalities; some of these municipalities are Batir, Husan, Nahaleen, Beit Jala Beit Sahour, and Al Khader. In addition it has three refugee camps and many rural districts. Regarding the weather in Bethlehem district, it has a Mediterranean climate, in other words, it has dry summers and mild winters. The temperature at summer stays around $30^{\circ} \mathrm{C}$, while in winter the temperature ranges from $1^{\circ} \mathrm{C}$ to $13^{\circ} \mathrm{C}$. Implicating to its rainfall, Bethlehem receives an average of 500 millimetres of rainfall annually [21]. The average relative humidity is around $60 \%$ and it gets to the highest rates during January and February, while in May it reaches the lowest levels. The main economic sector in Bethlehem governorate is tourism, in addition to other sectors that include industries, agricultural activities and trading [21].

\subsubsection{Site 2: Jenin District}

Jenin is one of the governorates of Palestine. It is located in the northern West Bank. It has a population of about 318,958 [22]. Jenin has a highest elevation of 


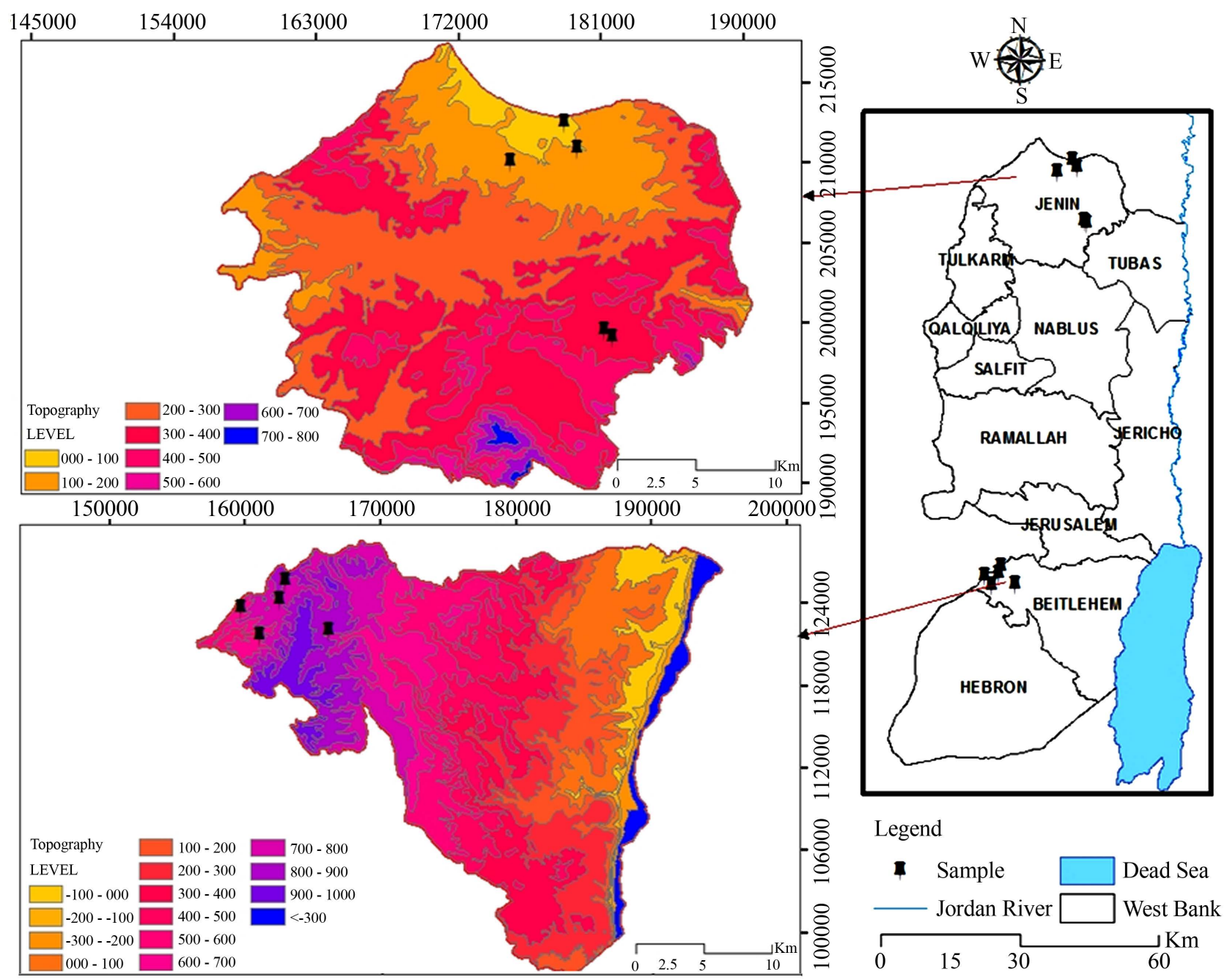

Figure 1. Jenin and Bethlehem regions with their topography and elevations.

about 250 meters above sea level, and its lowest is 90 meters above sea level. Jenin lies along the southern of Marj Ibn Amer, and to the northern along Jabal Nablus (23). In fact Jenin is 42 kilometers north of Nablus and 51 kilometers southeast of Haifa (24). The main economic sector in Jenin governorate is agriculture. Indeed the amount of employment by economic branch of total employed in rural Jenin is $45 \%$ in 2003 [23].

Implicating to its rainfall, Jenin receives an average of 530 millimetres of rainfall annually. The average relative humidity is around $69 \%$ and it gets to the highest rates during summer (22). Jenin is quite varied in the types of crops produced. This is mainly due to the type of soil, climate, and fair amounts of irrigation water and relatively high annual rainfall.

\subsection{Sampling Methods}

More than 50 samples of leafy vegetables were collected during late spring of 2018. The vegetable samples were grown on different farms within the study areas. Thirty samples were chosen for analysis. Fifteen of these samples were 
from Jenin's farms and fifteen were from Bethlehem farms. Three types of leafy vegetables were taken. These vegetables were Parsley, Spinach, and Arugula.

All collected samples were stored in clean plastic bags and brought to the laboratory for analysis.

Water samples were collected from each site for further analysis; the same water was used for irrigating these vegetables. Water was stored in clean plastic bottles washed with Distilled water. In site, the water bottle was washed with the same irrigating water then was filled with water [24].

In addition, soil samples were taken where the type of soils were terra Rossa in Bethlehem region and grumusols at Jenin zone. However, the soil that was collected was near the roots of the leafy vegetables within 5 to $10 \mathrm{~cm}$ depth [25].

Additionally, pesticides samples used on leafy vegetables were also collected for analysis. The samples were stored in clean plastic white bottles that are firmly closed and sent to the laboratory for analysis. Some of the pesticides samples were collected from the farms in both regions, while others were collected from the Ministry of Agriculture in Palestine.

\subsection{Preparation and Treatment of Samples}

The collected vegetable samples were washed with distilled water to remove dust particles. Then, samples were cut to small pieces. The leafy part was taken, and dried in an oven at $50^{\circ} \mathrm{C}$. After drying, the samples were ready for acid digestion.

For acid digestion, Microwave Digestion System (MARS6) was used which has a great speed, precision and high sensitivity. The method of digestion was given by the machine itself. The weight of each leaf was 0.5 grams. Then $50 \mathrm{ml}$ of $65 \%$ pure nitric acid were added to each sample. The mixture was then digested till the transparent solution was achieved. After cooling, the digested samples were filtered using CA sterile syringe filters with $30 \mathrm{~mm}$ diameter and pore size of $0.22 \mu \mathrm{m}$.

Heavy metals concentrations were determined using Inductively Couples Plasma Mass Spectrometry (ICP-MS) Agilent 7500.

For the soil samples, 50 grams of the soil were weighed and $250 \mathrm{ml}$ of milli-Q water were added. Milli-Q water is ultrapure water as defined by ISO 3696 (Merck Millipore Organization). The processes of purification include many steps of filtration and deionization to reach a purity characterised in term of resistivity 18.2 $\mathrm{M} \Omega \cdot \mathrm{cm}$ at $25^{\circ} \mathrm{C}$. Milli-Q purifiers produce water pure enough to get accuracy within parts per million (Yokoyama, et al.). Soil samples were kept for fourteen days, so that what surround the soil particles can be tested. This process was performed because it is not the soil particles that need to be analysed but the surroundings of the particles; in other words the leachate. $2 \mathrm{ml}$ of the sample were taken for analysis [25].

In addition, water samples were tested for the metal content by the addition of $65 \%$ pure nitric acid. $2 \mathrm{ml}$ of the sample were taken for analysis. Concerning pesticides samples, they were analysed by the use of ICP-MS Agilent 7500 [25]. 
For accurate quantitative determination of heavy metals in soil, water, vegetables and pesticides, an internal standard method was used using $\mathrm{Nd}$ as internal standard and a multi-standard calibration method: 22 metals standard (Ag 10 mg/L, Al 50 mg/L, B 50 mg/L, Ba 10 mg/L, Bi 100 mg/L, Ca 10 mg/L, Cd 10 $\mathrm{mg} / \mathrm{L}$, Co $10 \mathrm{mg} / \mathrm{L}, \mathrm{Cr} 50 \mathrm{mg} / \mathrm{L}, \mathrm{Cu} 10 \mathrm{mg} / \mathrm{L}$, Fe $10 \mathrm{mg} / \mathrm{L}, \mathrm{K} 100 \mathrm{mg} / \mathrm{L}$, Li 50 mg/L, Mg 10 mg/L, Mn 10 mg/L, Mo 50 mg/L, Na 50 mg/L, Ni 50 mg/L, Pb 100 $\mathrm{mg} / \mathrm{L}$, Sr $10 \mathrm{mg} / \mathrm{L}$, Tl $50 \mathrm{mg} / \mathrm{L}, \mathrm{Zn} 10 \mathrm{mg} / \mathrm{L}$, matrix 5\% $\mathrm{HNO}_{3}$ ). Samples were prepared by dilution of $1.0 \mathrm{~mL}$ of the water samples to $10.0 \mathrm{~mL}$ with $0.3 \%$ ultrapure nitric acid and analyzed by ICP/MS. Each sample was analyzed three times and the results are expressed as mean \pm SD (SD: standard deviation). Relative standard deviation (RSD) of the three results are calculated and found to be less than $5 \%$ for all samples for all metals analyzed in this study, reflecting the precision the method for the analysis of these heavy metals. Calibration curves for all metals analyzed were constructed by plotting the ratio of the intensity of the analyze metal to that of the internal standard $(\mathrm{Nd})$ vs. concentration of the trace metal (in ug/L), and results showed that the calibration curves are linear with correlation coefficient $\left(\mathrm{r}^{2}\right)$ greater than 0.999 for the trace metals analysed [24].

\section{Result and Discussion}

\subsection{Levels of Heavy Metals in Leafy Vegetables in Bethlehem Region}

Heavy metals concentrations in green leafy vegetables in Bethlehem region are presented in Table 1 . Results revealed variable concentrations of heavy metals in the leafy part of the vegetable samples.

The levels of iron (Table 1) in all vegetables ranged between $25.35 \mathrm{mg} / \mathrm{kg}$ and $1569.53 \mathrm{mg} / \mathrm{kg}$. Although leafy vegetables are rich with iron, however, in some samples they exceeded the limit given by WHO/FAO which is $425 \mathrm{mg} / \mathrm{kg}$ [20]. In fact, the concentrations of Fe in Batir in arugula and parsley samples are very high, $1045.94 \mathrm{mg} / \mathrm{kg}$ and $451.73 \mathrm{mg} / \mathrm{kg}$ respectively. The same as in spinach, arugula and parsley samples in Nahaleen, the Fe levels are $1569.53 \mathrm{mg} / \mathrm{kg}, 546.02$ $\mathrm{mg} / \mathrm{kg}$, and $567.61 \mathrm{mg} / \mathrm{kg}$ respectively. Regarding Lead contents, it varied from $0.03 \mathrm{mg} / \mathrm{kg}$ and $1.77 \mathrm{mg} / \mathrm{kg}$. Its concentration levels are relatively high in Batir samples and in Nahaleen. Chromium exceeded the allowable safety limits in arugula samples in two farms, Nahaleen and Batir. Zinc levels ranged from 3.61 $\mathrm{mg} / \mathrm{kg}$ and $106.5 \mathrm{mg} / \mathrm{kg}$, which is found in arugula sample in Nahaleen. The value is relatively high since the permissible limit given by FAO/WHO is 99.4 $\mathrm{mg} / \mathrm{kg}$ [20]. Concerning Cadmium, it was found that its concentration in Nahaleen in arugula sample is very high and relatively high in spinach sample. The observed concentrations of $\mathrm{Cr}, \mathrm{Mn}, \mathrm{Co}$, and $\mathrm{Cu}$ lies within the permissible limits set by $\mathrm{FAO} / \mathrm{WHO}$.

\subsection{Levels of Heavy Metals in Leafy Vegetables in Jenin Region}

As for Jenin region, results were quite different from Bethlehem region. Iron, 
Table 1. Heavy metals concentration $(\mathrm{mg} / \mathrm{kg})$ in leafy vegetables in Bethlehem region.

\begin{tabular}{|c|c|c|c|c|c|c|c|c|c|c|}
\hline $\begin{array}{l}\text { Farm } \\
\text { Name }\end{array}$ & $\begin{array}{c}\text { Sample } \\
\text { Name }\end{array}$ & $\begin{array}{c}\text { Sample } \\
\text { Weight } \\
\text { (g) }\end{array}$ & $\mathrm{Fe}$ & $\mathrm{Pb}$ & $\mathrm{Cr}$ & $\mathrm{Mn}$ & Co & $\mathrm{Cu}$ & $\mathrm{Zn}$ & $\mathrm{Cd}$ \\
\hline \multirow{3}{*}{ 壹 } & Spinach & 0.501 & $393.34 \pm 11.37$ & $0.36 \pm 0.007$ & $0.88 \pm 0.26$ & $58.5 \pm 2.8$ & $0.19 \pm 0.019$ & $14.3 \pm 1.26$ & $35.68 \pm 2.82$ & $0.17 \pm 0.07$ \\
\hline & Arugula & 0.503 & $1045.94 \pm 6.27$ & $1.77 \pm 0.16$ & $2.11 \pm 0.46$ & $31.78 \pm 0.41$ & $0.36 \pm 0.011$ & $10.75 \pm 1.49$ & $57.67 \pm 5.95$ & $0.14 \pm 0.03$ \\
\hline & Parsley & 0.505 & $451.73 \pm 6.68$ & $0.38 \pm 0.011$ & $0.6 \pm 0.12$ & $57.82 \pm 6.45$ & $50.11 \pm 0.017$ & $7.17 \pm 0.96$ & $47.7 \pm 1.98$ & $0.05 \pm 0.008$ \\
\hline \multirow{3}{*}{ 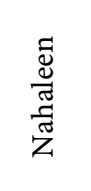 } & Arugula & 0.503 & $1569.53 \pm 7.53$ & $0.69 \pm 0.09$ & $2.51 \pm 0.86$ & $52.8 \pm 5.22$ & $0.48 \pm 0.02$ & $5.68 \pm 0.38$ & $106.5 \pm 3.07$ & $1.4 \pm 0.28$ \\
\hline & Spinach & 0.505 & $546.02 \pm 3.25$ & $0.53 \pm 0.04$ & $0.63 \pm 0.22$ & $43.06 \pm 1.91$ & $0.14 \pm 0.03$ & $13.49 \pm 1.13$ & $85.91 \pm 2.14$ & $0.26 \pm 0.04$ \\
\hline & Parsley & 0.506 & $567.61 \pm 2.4$ & $0.3 \pm 0.04$ & $0.66 \pm 0.30$ & $39.36 \pm 2.56$ & $50.14 \pm 0.03$ & $9.16 \pm 0.25$ & $53.37 \pm 2.06$ & $0.07 \pm 0.03$ \\
\hline \multirow{3}{*}{ 苞 } & Parsley & 0.503 & $126.81 \pm 4.67$ & $0.14 \pm 0.02$ & $0.49 \pm 0.16$ & $5.4 \pm 0.49$ & $0.02 \pm 0.008$ & $5.36 \pm 0.41$ & $7.64 \pm 1.08$ & $0.01 \pm 0.005$ \\
\hline & Spinach & 0.503 & $43.41 \pm 3.43$ & $0.12 \pm 0.03$ & $0.18 \pm 0.26$ & $10.98 \pm 0.52$ & $0.06 \pm 0.03$ & $1.43 \pm 2.24$ & $30.43 \pm 1.51$ & $0.06 \pm 0.03$ \\
\hline & Arugula & 0.508 & $45.73 \pm 5.49$ & $0.17 \pm 0.02$ & $0.04 \pm 0.06$ & $6.63 \pm 0.49$ & $0.05 \pm 0.01$ & $1.35 \pm 0.12$ & $29.35 \pm 2.63$ & $0.02 \pm 0.06$ \\
\hline \multirow{3}{*}{$\begin{array}{l}\tilde{\pi} \\
3 \\
3\end{array}$} & Arugula & 0.5023 & $75.04 \pm 3.59$ & $0.13 \pm 0.03$ & $0.02 \pm 0.02$ & $10.68 \pm 0.81$ & ND & $0.85 \pm 0.14$ & $5.5 \pm 0.79$ & $0.08 \pm 0.02$ \\
\hline & Parsley & 0.504 & $89.86 \pm 8.69$ & $0.28 \pm 0.012$ & $0.02 \pm 0.06$ & $29.91 \pm 2.51$ & $10.01 \pm 0.015$ & $1.93 \pm 0.15$ & $9.1 \pm 0.65$ & $0.02 \pm 0.006$ \\
\hline & Spinach & 0.503 & $25.35 \pm 4.42$ & $0.03 \pm 0.011$ & $0.02 \pm 0.02$ & $2.22 \pm 0.08$ & $0.10 \pm 0.02$ & $0.81 \pm 0.08$ & $3.61 \pm 0.46$ & $0.01 \pm 0.007$ \\
\hline \multirow{3}{*}{ 它胥 } & Arugula & 0.508 & $165.48 \pm 3.0$ & $0.08 \pm 0.04$ & $0.28 \pm 0.08$ & $6.59 \pm 1.20$ & $0.07 \pm 0.006$ & $0.56 \pm 0.14$ & $4.24 \pm 0.89$ & $0.03 \pm 0.009$ \\
\hline & Parsley & 0.504 & $208.99 \pm 5.27$ & $0.32 \pm 0.05$ & $0.44 \pm 0.15$ & $19.62 \pm 0.35$ & $50.12 \pm 0.03$ & $1.05 \pm 0.11$ & $6.4 \pm 0.43$ & ND \\
\hline & Spinach & 0.5003 & $88.7 \pm 9.33$ & $0.04 \pm 0.004$ & $0.15 \pm 0.17$ & $3.43 \pm 0.08$ & $0.05 \pm 0.02$ & $0.87 \pm 0.18$ & $4.15 \pm 0.77$ & $0.01 \pm 0.032$ \\
\hline \multicolumn{3}{|c|}{ WHO/FAO Safe limits } & 425 & 0.3 & 1.3 & 500 & 50 & 73 & 99.4 & 0.2 \\
\hline
\end{tabular}

Lead, Copper and Cadmium revealed relatively high levels in some samples of leafy vegetables. Regarding Iron, its concentration is high in arugula sample located at Zababdeh farm, and relatively high in parsley and spinach sample at the same farm (see Table 2).

Iron concentration was high in three samples taken from the Zababdeh farm (Table 2). The permissible limit set by WHO for Fe is $425 \mathrm{mg} / \mathrm{kg}$. Additionally, it was found that Lead levels of some vegetables sample obtained from Jenin farms exceeded the safe limits established by FAO/WHO for human consumption. The highest concentrations of $\mathrm{Pb}$ are $0.32 \mathrm{mg} / \mathrm{kg}$ and $0.67 \mathrm{mg} / \mathrm{kg}$; are found in parsley and spinach samples located at Zababdeh farm; and $0.47 \mathrm{mg} / \mathrm{kg}$ in parsley sample located at kofr Than farm.

From the present analysis, it can be noticed that Cadmium is relatively high in one of the samples which is spinach at Zababdeh farm. The allowable limit for $\mathrm{Cd}$ in leafy vegetables is $0.2 \mathrm{mg} / \mathrm{kg}$ (see Table 2) [20]. Similarly to the case with lead in Zababdeh farm.

However, other heavy metals such as $\mathrm{Cr}, \mathrm{Co}, \mathrm{Mn}$, and $\mathrm{Zn}$ contain levels below the WHO/FAO safety limits. 
Table 2. Heavy metals concentration $(\mathrm{mg} / \mathrm{kg})$ in leafy vegetables in Jenin region.

\begin{tabular}{|c|c|c|c|c|c|c|c|c|c|c|}
\hline $\begin{array}{l}\text { Farm } \\
\text { Name }\end{array}$ & $\begin{array}{l}\text { Sample } \\
\text { Name }\end{array}$ & $\begin{array}{c}\text { Sample } \\
\text { Weight } \\
\text { (g) }\end{array}$ & $\mathrm{Fe}$ & $\mathrm{Pb}$ & $\mathrm{Cr}$ & Mn & Co & $\mathrm{Cu}$ & $\mathrm{Zn}$ & Cd \\
\hline \multirow{3}{*}{$\begin{array}{l}\text { त्ञ } \\
\widetilde{\pi}\end{array}$} & Arugula & 0.501 & $164.80 \pm 5.67$ & $0.08 \pm 0.03$ & $0.17 \pm 0.05$ & $11.33 \pm 0.48$ & $0.01 \pm 0.005$ & $0.62 \pm 0.08$ & $9.15 \pm 0.65$ & $0.17 \pm 0.05$ \\
\hline & Spinach & 0.505 & $90.04 \pm 3.15$ & $0.05 \pm 0.02$ & $0.03 \pm 0.18$ & $14.50 \pm 5.98$ & $0.01 \pm 0.02$ & $1.02 \pm 33.4$ & $4.22 \pm 2.93$ & $0.02 \pm 0.04$ \\
\hline & Parsley & 0.506 & $291.98 \pm 2.33$ & $0.24 \pm 0.01$ & $0.29 \pm 0.33$ & $64.36 \pm 2.06$ & $0.12 \pm 0.312$ & $278.50 \pm 0.13$ & $322.31 \pm 0.70$ & $0.06 \pm 0.03$ \\
\hline \multirow{3}{*}{ 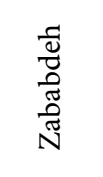 } & Arugula & 0.505 & $543.10 \pm 11.40$ & $0.23 \pm 0.04$ & $0.77 \pm 0.05$ & $15.56 \pm 2.25$ & $0.20 \pm 0.01$ & $2.05 \pm 0.27$ & $15.62 \pm 1.65$ & $0.07 \pm 0.04$ \\
\hline & Parsley & 0.503 & $443.04 \pm 8.69$ & $0.32 \pm 0.01$ & $0.53 \pm 0.16$ & $117.37 \pm 18.10$ & $00.31 \pm 0.08$ & $4.58 \pm 0.30$ & $44.54 \pm 1.86$ & $0.06 \pm 0.02$ \\
\hline & Spinach & 0.551 & $475.84 \pm 8.82$ & $0.67 \pm 0.09$ & $0.42 \pm 0.08$ & $47.61 \pm 3.55$ & $0.17 \pm 0.05$ & $5.29 \pm 0.75$ & $42.61 \pm 4.59$ & $1.62 \pm 0.13$ \\
\hline \multirow{3}{*}{ 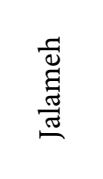 } & Arugula & 0.506 & $50.30 \pm 6.69$ & $0.13 \pm 0.20$ & ND & $5.32 \pm 0.72$ & $0.03 \pm 0.01$ & $1.03 \pm 0.42$ & $24.94 \pm 3.27$ & $0.06 \pm 0.07$ \\
\hline & Parsley & 0.521 & $60.92 \pm 0.30$ & $0.09 \pm 0.013$ & ND & $16.12 \pm 2.73$ & $0.04 \pm 0.008$ & $1.49 \pm 0.09$ & $18.44 \pm 2.53$ & $0.01 \pm 0.013$ \\
\hline & Spinach & 0.500 & $75.09 \pm 8.01$ & $0.11 \pm 0.05$ & $0.15 \pm 0.37$ & $10.21 \pm 1.63$ & $0.06 \pm 0.03$ & $2.59 \pm 0.62$ & $25.83 \pm 4.82$ & $0.03 \pm 0.07$ \\
\hline \multirow{3}{*}{ 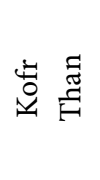 } & Arugula & 0.505 & $91.58 \pm 5.7$ & $0.03 \pm 0.029$ & ND & $2.38 \pm 0.24$ & $0.02 \pm 0.007$ & $1.60 \pm 0.14$ & $2.79 \pm 0.27$ & $0.01 \pm 0.025$ \\
\hline & Parsley & 0.501 & $37.85 \pm 4.16$ & $0.47 \pm 0.13$ & ND & $8.85 \pm 0.15$ & $0.06 \pm 0.03$ & $1.89 \pm 0.24$ & $16.44 \pm 0.99$ & $0.04 \pm 0.05$ \\
\hline & Spinach & 0.500 & $84.90 \pm 6.4$ & $0.07 \pm 0.09$ & ND & $10.91 \pm 0.54$ & $0.07 \pm 0.02$ & $0.88 \pm 0.22$ & $43.78 \pm 2.46$ & $0.02 \pm 0.03$ \\
\hline \multirow{3}{*}{ 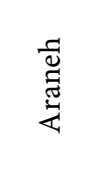 } & Arugula & 0.500 & $42.35 \pm 0.67$ & $0.11 \pm 0.10$ & $0.08 \pm 0.31$ & $0.27 \pm 0.09$ & $0.04 \pm 0.01$ & $0.55 \pm 0.02$ & $23.66 \pm 3.08$ & ND \\
\hline & Parsley & 0.502 & $83.43 \pm 8.6$ & $0.24 \pm 0.09$ & $0.27 \pm 0.24$ & $14.29 \pm 3.10$ & $0.06 \pm 0.01$ & $1.71 \pm 0.11$ & $30.43 \pm 2.57$ & $0.02 \pm 0.01$ \\
\hline & Spinach & 0.504 & $86.21 \pm 614.2$ & $0.19 \pm 0.03$ & $0.11 \pm 0.16$ & $7.01 \pm 0.30$ & $0.08 \pm 0.02$ & $1.50 \pm 0.08$ & $30.45 \pm 1.35$ & $0.02 \pm 0.06$ \\
\hline \multicolumn{3}{|c|}{ WHO/FAO Safety limits } & 425 & 0.3 & 1.3 & 500 & 50 & 73 & 99.4 & 0.2 \\
\hline
\end{tabular}

\subsection{Concentration of Heavy Metals in the Water Used for Irrigation}

Groundwater in the West Bank from wells and springs is the major source of water being used for irrigation [17].

\subsubsection{Bethlehem Region}

Our results show that there is no heavy metal contamination in water samples in Bethlehem region since all concentrations lie within the permissible safety limits set by $\mathrm{FAO} / \mathrm{WHO}$ for irrigation water.

\subsubsection{Jenin Region}

It was also found that the used irrigation water does not contain any exceeded levels of heavy metals according to FAO/WHO standards. It is however important to say that in Jenin Districts, groundwater consists of aquifer systems that are located and recharged from rainfall in the West Bank. In addition, some farms depend on agricultural wells for irrigation.

\subsection{Heavy Metals Concentrations in Leachate Soil Samples}

It was found that all metals for all soil samples in Bethlehem farms and Jenin farms do not exceed the permissible limits given by FAO/WHO. Based on these 
results, it can be said that no heavy metals contamination in vegetables samples could have resulted from the soil.

In Figure 2 which shows heavy metals concentration in soil samples at Bethlehem region, it can be seen that Fe levels are higher than other metals and its concentration is the highest at Batir. However, it still lies within the allowable limit for soil set by FAO/WHO [20].

It is also noticed that cadmium is not exist in soil samples as well as chromium or have not been detected by the machine due to its low value. In addition, other heavy metals such as $\mathrm{Mn}, \mathrm{Co}, \mathrm{Cu}, \mathrm{Pb}$ and $\mathrm{Zn}$ are found in very small amounts in the soil.

In Figure 3, it can be seen that Chromium and Cadmium do not exist in these soil samples or they are below the detection limit of the machine. In addition, $\mathrm{Fe}$ is the most available heavy metal but does not exceed the permissible limit set by FAO/WHO. It can be also noticed that Manganese exists in Kofr Than farm quite higher compared to other farms. Still, none of these metals is harmful or has any effects within their existed concentrations.

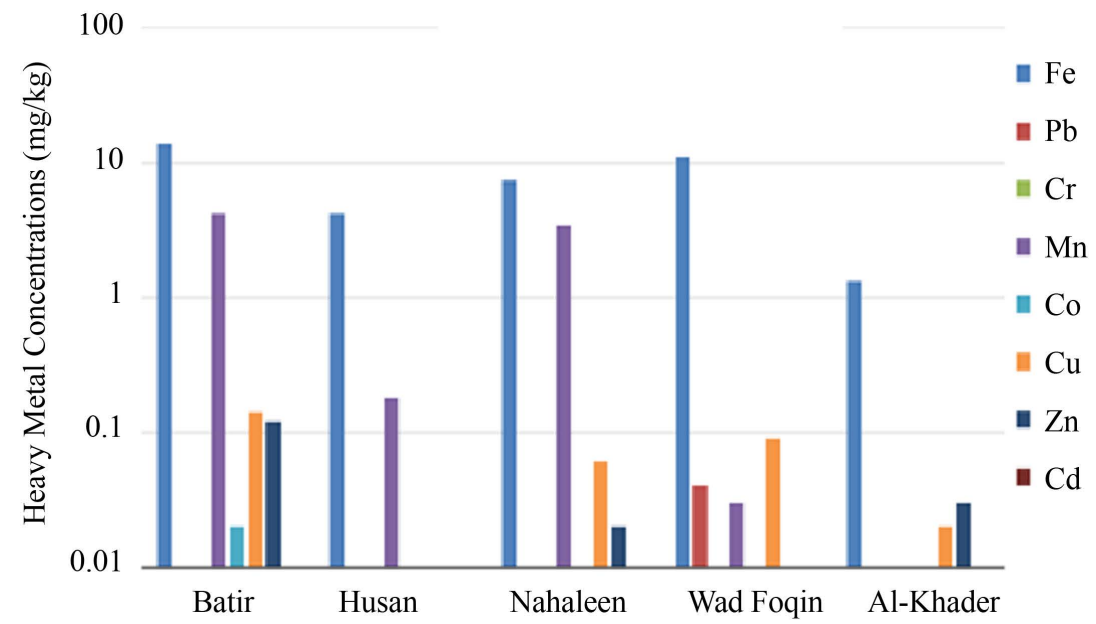

Figure 2. Heavy metals concentration in soil samples in Bethlehem region.

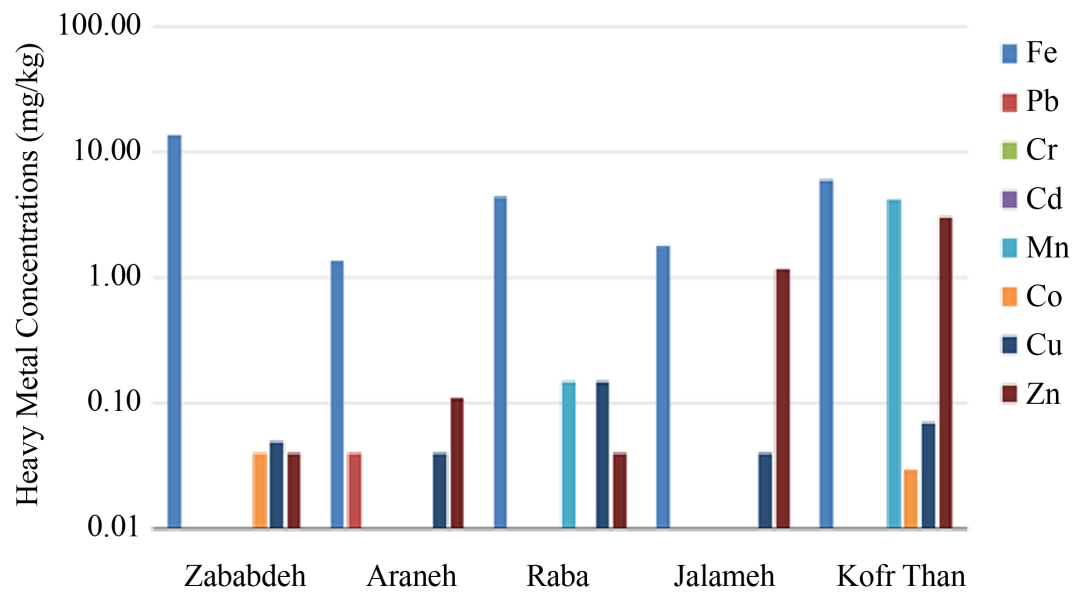

Figure 3. Heavy metals concentrations in soil samples collected from Jenin farms. 
However, when comparing level concentrations of heavy metals in both regions, it can be seen that $\mathrm{Fe}$ has the highest value among other elements in all soil samples. Manganese takes the second place then Zinc. All other heavy metals have very low concentrations in soil (see Figure 4). The presented results of heavy metals in soil indicate that heavy metal content in soil is not relevant to heavy metal contamination found in leafy vegetables.

\subsection{Heavy Metals Concentrations in Pesticide Samples}

Pesticides samples that were used on leafy vegetables were analyzed for their heavy metals content levels. Table 3 shows some of the used pesticides with their

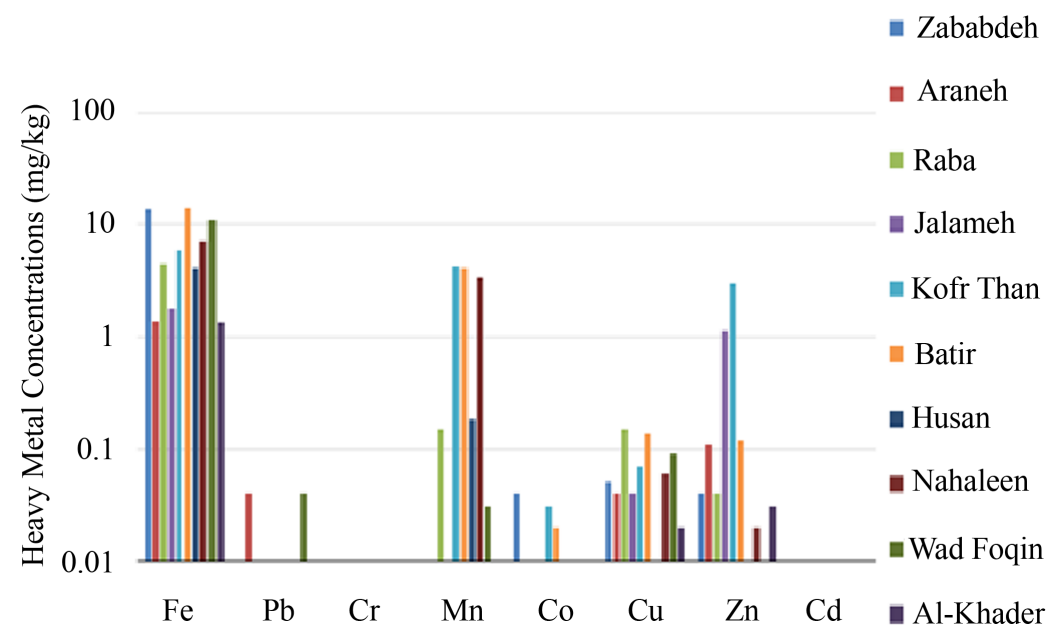

Figure 4. Heavy metals concentrations from soil samples from Bethlehem and Jenin farms.

Table 3. Heavy metals concentration $(\mathrm{mg} / \mathrm{l})$ in pesticides samples.

\begin{tabular}{|c|c|c|c|c|c|c|c|c|}
\hline $\begin{array}{l}\text { Sample } \\
\text { Name }\end{array}$ & $\mathrm{Pb}$ & $\mathrm{Cr}$ & $\mathrm{Mn}$ & $\mathrm{Fe}$ & Co & $\mathrm{Cu}$ & $\mathrm{Zn}$ & $\mathrm{Cd}$ \\
\hline & 0.003 & & & \pm 0.68 & & & 93 & 0.0 \\
\hline $\mathrm{Nee}$ & $0.160 \pm 0.026$ & $0.033 \pm 0.050$ & $0.029 \pm 0.016$ & & $0.002 \pm 0.001$ & $0.031 \pm 0.013$ & $2.736 \pm 0.048$ & $0.008 \pm 0.008$ \\
\hline $\mathrm{Kur}$ & & & & & & & & 80.079 \\
\hline Verti & $0.132 \pm 0.012$ & $0.016 \pm 0.010$ & & $0.426 \pm 0.277$ & $0.003 \pm 0.003$ & $0.031 \pm 0.013$ & $1.348 \pm 0.008$ & $0.008 \pm 0.003$ \\
\hline Timor C & $0.247 \pm 0.005$ & $0.112 \pm 0.062$ & $0.562 \pm 0.046$ & $198.94 \pm 17.26$ & $0.027 \pm 0.003$ & $0.133 \pm 0.002$ & $30.551 \pm 0.251$ & $10.007 \pm 0.009$ \\
\hline $\mathrm{Ag}_{1}$ & $0.090 \pm$ & $0.302 \pm 0.241$ & & & & & & $0.006 \pm 0.006$ \\
\hline Defe & $0.295 \pm$ & $0.032 \pm 0.100$ & $3.493 \pm 0.58$ & & $0.007 \pm 0.004$ & $0.012 \pm 0.025$ & $2.196 \pm 0.041$ & $0.013 \pm$ \\
\hline Siperin 10 & $0.056 \pm 0.002$ & $0.306 \pm 0.291$ & $0.299 \pm 0.051$ & $8.705 \pm 1.45$ & $0.012 \pm 0.003$ & $0.041 \pm 0.023$ & $0.761 \pm 0.015$ & $0.007 \pm 0.003$ \\
\hline Bio-T plus & $0.152 \pm 0.016$ & $0.038 \pm 0.117$ & $19.64 \pm 0.99$ & $25.458 \pm 1.91$ & $0.008 \pm 0.004$ & $9.186 \pm 0.486$ & $21.838 \pm 0.076$ & $60.016 \pm 0.012$ \\
\hline Match & $0.095 \pm 0.013$ & $0.057 \pm 0.054$ & $0.177 \pm 0.035$ & $9.614 \pm 0.27$ & $0.009 \pm 0.001$ & $0.038 \pm 0.030$ & $1.166 \pm 0.016$ & $0.009 \pm 0.012$ \\
\hline $\begin{array}{c}\text { WHO/FAO } \\
\text { Limit }\end{array}$ & 0.1 & 0.05 & ND & ND & ND & 0.1 & 15.0 & 0.06 \\
\hline
\end{tabular}


heavy metal concentration in $\mathrm{mg} / \mathrm{l}$. Generally, these pesticide types are the ones often used by farmers when planting and growing leafy vegetables whether in Bethlehem or Jenin regions. Some of these types are used for organic agriculture; others are used as insecticides or nematicide as well as acaricides.

It can be noticed that some metals are presented in relatively high concentration, particularly Iron, Lead, and Zinc. It is noticeable that these concentrations exceeded the permissible limit set by WHO/FAO regarding the presence of heavy metals in pesticides. Obviously, Iron is the most available heavy metal in the pesticides samples used on leafy vegetables. Zinc actually takes the second place regarding its availability in the selected pesticides. Other heavy metals are found in variable amounts as shown in the previous table.

These pesticide types are legal to be used according to the Ministry of Agriculture in the West Bank. Thus using them will not pose a direct problem; however, the validity of such pesticides depends on its concentration and the usage method; whether it is being used in the allowable concentration, or if being diluted correctly, etc.

Additionally, it is important to acknowledge that plenty of pesticides used by Palestinian farmers are illegal according to officials' statements and controllers at the Ministry of Agriculture. Besides, the smuggled illegal pesticides play a direct role in contamination of vegetables as confirmed by Ministry of Agriculture. Other sources in the West Bank confirm the same statement including the Palestinian Central Bureau of Statistics that reported the excessive use of pesticides where $50 \%$ of these pesticides were insecticides. In addition to another institute which is Applied Research Institute Jerusalem (ARIJ) [17] that collected background data about pesticides use in the West Bank, where results had shown widespread problems in both usage and disposal of pesticides. Some of the pesticides used in the West Bank are suspended, cancelled or banned by the World Health Organization [26].

Table 4 shows the generic name of each pesticide along with the concentration of the active ingredient in addition to the category that each pesticide belongs to; it can be noticed that the concentration of the active ingredient varies. These pesticides are found in forms of emulsifiable concentrate, wettable powder, soluble liquid concentrate, soluble powder, suspension concentrate, capsule suspensions, and water dispersible granules.

However, it is quite obvious that the presence of heavy metals in leafy vegetable samples is directly related to the use of some of these pesticides. Probably the pesticides were being mixed wrongly, mishandled and misused. As stated by the Palestinian Central Bureau of Statistics in 2010, the use of pesticides in the West Bank is excessive. Thus, it can be concluded that pesticides have a major role in the contamination found in leafy vegetable samples. Other related Palestinian studies in the West Bank assured that most farmers need more educational programs regarding the safety and the use of pesticides.

To further explain the results, starting with Fe levels in leafy vegetables at Bethlehem region (see Table 1) which is not found in contamination levels 
Table 4. Detailed information about the pesticides samples.

\begin{tabular}{ccccc}
\hline $\begin{array}{c}\text { Sample } \\
\text { Name }\end{array}$ & Generic Name & Type & $\begin{array}{c}\text { Active Ingredient } \\
\text { Concentration }\end{array}$ & $\begin{array}{c}\text { Source of Collection } \\
\text { of Pesticide }\end{array}$ \\
\hline Mafisto & Acetamiprid & Insecticide & $200 \mathrm{~g} / \mathrm{L}$ & Ministry of Agriculture \\
Neemacor & Fenamiphos & Nematicide and Insecticide & $400 \mathrm{~g} / \mathrm{L}$ & Ministry of Agriculture \\
Kung Fu & Lambda Cyhalothrin & Pesticide & $50 \mathrm{~g} / \mathrm{L}$ & Bethlehem and Jenin Farms \\
Vertimec & Abamectin & Insecticide & $18 \mathrm{~g} / \mathrm{L}$ & Ministry of Agriculture \\
Timor C & Pyrethrin & Organic Control Material & $15 \mathrm{~g} / \mathrm{L}$ & Bethlehem Farms \\
Agriron & Abamectin & Acaricide & $18 \mathrm{~g} / \mathrm{L}$ & Jenin Farms \\
Defender & Cyflumetofen & Pesticide & $215 \mathrm{~g} / \mathrm{L}$ & Jenin Farms \\
Siperin 10 & Cypermethrin & Insecticide and Acaricide & $100 \mathrm{~g} / \mathrm{L}$ & Ministry of Agriculture \\
Bio-T plus & Bacillus Thuringiensis & Organic Control Material & $16 \mathrm{~g} / \mathrm{L}$ & Bethlehem and Jenin Farms \\
Match & Lufenuron & Insecticide & $50 \mathrm{~g} / \mathrm{L}$ & Ministry of Agriculture \\
\hline
\end{tabular}

neither in irrigation water or leachate soil, then its presence in vegetables samples mainly in Nahaleen and Batir is related to pesticides appliance. In particular, due to usage of Timor $\mathrm{C}$ and Kung Fu Pesticides. As for $\mathrm{Pb}$ source, the reason could also be connected to pesticides especially kung Fu, and Defender. Concerning the source of $\mathrm{Cr}$ in the same region, it can be linked to the utilization of either Kung Fu, Agriron, or Siperin 10. In addition. Zn levels in Nahaleen Farm is relevant to the use of Timor $\mathrm{C}$ or Bio-T plus pesticides. Whereas for $\mathrm{Cd}$ levels in Nahaleen, the results leads back to the use of Kung Fu (note the concentrations of heavy metals in Table 4).

Therefore, it can be concluded that the present heavy metal contamination is due to pesticides appliances in the mentioned farms in Bethlehem region. Specifically speaking, samples in Nahaleen and Batir showed high concentrations of heavy metals which were relevant to specific pesticides including Timor C, Kung $\mathrm{Fu}$, Defender, Bio-T, Agriron and Siperin 10. However, the values obtained varied between one vegetable type and the other due to the quantity differences, dilution method, concentration of each pesticide, and the rate of exposure.

Still, there could be a possibility of contamination due to rapid industrialization and urbanization in the above areas in Bethlehem region. Thus, through atmospheric deposits, heavy metals can be absorbed into the plant tissues.

In addition to that, Fe concentration which was observed high in some samples, could be a result of use of iron chelate, which is a soluble complex of iron and chelating agent that is sprayed to plants to treat chlorosis; a condition in which leaves produce insufficient chlorophyll. The high results appeared in plants not in soil samples, because iron chelate is not held by the soil, and does not go under hydrolysis or biodegradation but easily absorbed by the plant. However, this remains a possibility and cannot be assured since there were no collected samples of iron chelate to analyse. 
Regarding Jenin region, iron levels exceeded the permissible limits set by $\mathrm{WHO} /$ FAO in Zababdeh farm, and the reason for such result was confirmed to be the use of Kung Fu. However, it is noticeable that the used quantity of this pesticide was not the same as in Bethlehem farms since the concentrations were lower compared to those in Bethlehem. Similarly the concentration of lead at Zababdeh farm and Kofr Than farm were the results were also linked to the use of Kung Fu and Defender.

Additionally, copper as apparent in Figure 2 exceeded the limit in Parsley sample at Raba farm. It can be considered that parsley in that farm was exposed to copper containing pesticide though in small portions. These pesticides could include Bio-T plus or Agriron.

In regards to cadmium (see Figure 3), which is relatively high in spinach at Zababdeh farm, the cause for this result could be the exposure of spinach to other types of pesticides but in low portions.

However, it is believed that other farms such as Araneh, Jalameh, Husan, Wad foqin, and AlKhader use pesticides for improving their production but with regards to the allowable limits and according to regulations set by the Ministry of Agriculture. This could be the reason why leafy vegetables in these farms were not contaminated with noticeable heavy metals.

It is important to acknowledge that long term consumption of heavy metal contaminated vegetables may possibly cause numerous health hazards in human. Therefore, regular monitoring of heavy metals is crucial to avoid excessive build-up of these metals in human food chain especially that some pesticides could be illegal; even if legal, some can be misused or misapplied whether by the quantity, exposure rate and duration, or the dilution method.

\section{Conclusions}

From the present study, it can be concluded that some heavy metals $(\mathrm{Fe}, \mathrm{Pb}, \mathrm{Cr}$, $\mathrm{Cu}, \mathrm{Zn}, \mathrm{Cd}$ ) concentrations in some green leafy vegetables obtained from Bethlehem and Jenin regions were above the permissible limits set by FAO/WHO for human consumption. However, levels of $\mathrm{Mn}$ and $\mathrm{Co}$ in all leafy vegetables collected were found below the maximum allowable limit. The results also indicated that the source of contamination was due to pesticides. Some pesticides could have been misused whether by the concentration or the quantity or even the dilution process. Despite the significant relation between water, soil and vegetables, there was no clear evidence that contamination results from any of these parameters.

The results reveal that farmers apply pesticides in violation of the recommendations, use high concentrations, and use illegal unsafe chemicals, and ignore risks and safety instructions.

Yet, long term consumption of heavy metals may cause several health hazards in humans. Thus, regular monitoring of heavy metals in leafy vegetables is crucial to avoid the accumulation of such metals in the human food chain, also more attention should be paid to pesticides. 


\section{Conflicts of Interest}

The authors declare no conflicts of interest regarding the publication of this paper.

\section{References}

[1] He, Z.L., Yang, X.E. and Stoffella, P.J. (2005) Trace Elements in Agroecosystems and Impacts on the Environment. Journal of Trace Elements in Medicine and Biology, 19, 125-140. https://doi.org/10.1016/j.jtemb.2005.02.010

[2] Kabata-Pendias, A. (2000) Trace Elements in Soils and Plants. 3rd Edition, CRC Press, Boca Raton.

[3] Mamtani, R., Stern, P., Dawood, I. and Cheema, S. (2011) Metals and Disease: A Global Primary Health Care Perspective. Journal of Toxicology, 2011, Article ID: 319136. https://doi.org/10.1155/2011/319136

[4] Hussain, A., Priyadarshi, M. and Dubey, S. (2019) Experimental Study on Accumulation of Heavy Metals in Vegetables Irrigated with Treated Wastewater. Applied Water Science, 9, Article No. 122. https://doi.org/10.1007/s13201-019-0999-4

[5] Kapri, A., Mohammed, A.S. and Goel, R. (2011) Heavy Metal Pollution: Source, Impact, and Remedies. In: Khan, M., Zaidi, A., Goel, R. and Musarrat J., Eds., Biomanagement of Metal-Contaminated Soils, Springer, Dordrecht, 1-28. https://doi.org/10.1007/978-94-007-1914-9_1

[6] Yuan, W.Z., Yang, N. and Li, X.K. (2016) Advances in Understanding How Heavy Metal Pollution Triggers Gastric Cancer. BioMed Research International, 2016, Article ID: 7825432. https://doi.org/10.1155/2016/7825432 https://www.hindawi.com/journals/bmri/2016/7825432/

[7] Khalilia, W. (2020) Assessment of Lead, Zinc and Cadmium Contamination in the Fruit of Palestinian Date Palm Cultivars Growing at Jericho Governorate. Journal of Biology, Agriculture and Healthcare, 10, 7-14.

[8] Bradl, H. (2005) Sources and Origins of Heavy Metals. In: Bradl, H., Ed., Heavy Metals in the Environment: Origin, Interaction and Remediation, Elsevier, Amsterdam, $120 \mathrm{p}$.

[9] Oluwole, S., Olubunmi, M., Yusuf, K., Fajana, O. and Odumosu, A. (2013) Determination of Heavy Metal Contaminants in Leafy Vegetables Cultivated by the Roadside. International Journal of Engineering Research and Development, 7, 1-5.

[10] Swaileh, K.M., Hussein, R.M. and Abu-Elhaj, S. (2004) Assessment of Heavy Metal Contamination in Roadside Surface Soil and Vegetation from the West Bank. Archives of Environmental Contamination and Toxicology, 47, 23-30. https://doi.org/10.1007/s00244-003-3045-2

[11] Arora, M., Kiran, B., Rani, S., Rani, A., Kaur, B. and Mittal, N. (2008) Heavy Metal Accumulation in Vegetables Irrigated with Water from Different Sources. Food Chemistry, 111, 811-815. https://doi.org/10.1016/j.foodchem.2008.04.049

[12] McLaughlin, M.J., Smolders, E., Degryse F. and Rietra, R. (2011) Uptake of Metals from Soil into Vegetables. In: Swartjes, F., Ed., Dealing with Contaminated Sites. From Theory towards Practical Application, Springer, Dordrecht, 325-367. https://doi.org/10.1007/978-90-481-9757-6_8

[13] García, M.A., Alonso, J. and Melgar, M.J. (2009) Lead in Edible Mushrooms: Levels and Bioaccumulation Factors. Journal of Hazardous Materials, 167, 777-783.

https://doi.org/10.1016/j.jhazmat.2009.01.058 
[14] Jiao, W.T., Chen, W.P., Chang, A.C. and Page, A.L. (2012) Environmental Risks of Trace Elements Associated with Long-Term Phosphate Fertilizers Applications: A Review. Environmental Pollution, 168, 44-53. https://doi.org/10.1016/j.envpol.2012.03.052

[15] European Union (2006) Commission Regulation (EC) No. 1881/2006 of 19 December 2006 Setting Maximum Levels for Certain Contaminants in Foodstuffs. Official Journal of the European Union, 364, 5-24.

[16] American Near East Refugee Aid (2013) Agriculture in the West Bank and Gaza. ANERA Improving Lives in the Middle East. ANERA, Washington DC.

[17] Isaac, J., Khair, A., Hilal, J., et al. (2011) Status of the Environment in the Occupied Palestinian Territory, a Human Rights-Based Approach. Applied Research Institute Jerusalem (ARIJ), Bethlehem.

[18] Center Palestinian National Information (2011) Impact of the Israeli Colonies on the Palestinian Environment. Palestinian News and Info Agency.

http://info.wafa.ps/atemplate.aspx?id=4073\#

[19] Abualhasan, M., Jaradat, N., Sawaftah, Z., Mohsen, H., Najjar, D. and Zareer, W. (2019) Evaluation of Heavy Metals and Microbiological Contamination of Selected herbals from Palestine. Open Life Sciences, 14, 448-453.

https://doi.org/10.1515/biol-2019-0050

[20] FAO/WHO (2011) Joint FAO/WHO Food Standards Programme Codex Committee on Contaminants in Foods. 21-25.

[21] Isaac, J., Salem, S.S., Hilal, J., et al. (2007) Status of the Environment in the Occupied Palestinian Territory. Applied Research Institute Jerusalem (ARIJ), Bethlehem.

[22] Palestinian Central Bureau of Statistics (2016) Palestine in Figures. Ramallah.

[23] Al-Khatib, I.A., Arafeh, G., Al-Qutob, M., Jodeh, S., Hasan, A., Jodeh, D. and van der Valk, M. (2019) Health Risk Associated with Some Trace and Some Heavy Metals Content of Harvested Rainwater in Yatta Area, Palestine. Water, 11, Article No. 238. https://doi.org/10.3390/w11020238

[24] Malassa, H., Al-Qutob, M., Al-Khatib, M. and Al-Rimawi, F. (2013) Determination of Different Trace Heavy Metals in Ground Water of South West Bank/Palestine by ICP/MS. Journal of Environmental Protection, 4, 818-827. https://doi.org/10.4236/jep.2013.48096

[25] Aweng, E.R., Karimah, M. and Suhaimi, O. (2011) Heavy Metals Concentration of Irrigation Water, Soils and Fruit Vegetables in Kota Bharu Area, Kelantan, Malaysia. Journal of Applied Sciences in Environmental Sanitation, 6, 463-470.

[26] United Nations Environment Programme (2020) State of Environment and Outlook Report for the Occupied Palestinian Territory 2020.

https://www.unep.org/resources/report/state-environment-and-outlook-report-occ upied-palestinian-territory-2020 